\title{
Legislative Actions of the Republic of Poland Government and Religious Attitudes of Muslims in Poland during the COVID-19 Pandemic
}

\author{
Wojciech Kostecki and Aldona Maria Piwko*
}

Citation: Kostecki, Wojciech, and Aldona Maria Piwko. 2021.

Legislative Actions of the Republic of Poland Government and Religious Attitudes of Muslims in Poland during the COVID-19 Pandemic. Religions 12: 335 . https://doi.org/ $10.3390 /$ rel12050335

Academic Editors:

Anna Jupowicz-Ginalska,

Iwona Leonowicz-Bukała and Andrzej Adamski

Received: 21 April 2021

Accepted: 8 May 2021

Published: 11 May 2021

Publisher's Note: MDPI stays neutral with regard to jurisdictional claims in published maps and institutional affiliations.

Copyright: (C) 2021 by the authors Licensee MDPI, Basel, Switzerland. This article is an open access article distributed under the terms and conditions of the Creative Commons Attribution (CC BY) license (https:// creativecommons.org/licenses/by/ $4.0 /$ )
Institute of Research in the Discipline of Political Science and Administration, Faculty of Business and International Relations, Vistula University, 02-787 Warszawa, Poland; w.kostecki@vistula.edu.pl

* Correspondence: a.piwko@vistula.edu.pl

Abstract: The main objective of this paper is to determine the religious attitudes of Muslims living in Poland during the COVID-19 pandemic and their reaction to restrictions on free access to religious practices introduced by the Government of Poland. The article is interdisciplinary, and the methodology combines elements of religious studies, political science of religion, and reference to communication and media studies (the importance of the role of the media in supporting government activities and the analysis of online access to Islamic religiosity during a pandemic). The study was conducted in February 2021, but the time frame of the analyzed issues ranges from 4 March 2020 to 28 February 2021, i.e., the year of the epidemic in Poland and the introduction by the Government of restrictions on religious gatherings and the response of the Muslim community to these restrictions. The analysis was carried out on the basis of the author's in-depth interview scenario; it covers representatives of the clergy, religious teachers, and the boards of major Muslim religious unions and associations, as well as Islamic cultural foundations and the attitudes of believers. The study showed that the media and Internet publicity accompanying the introduction of government restrictions and restrictions had a greater impact on society than the civil rights guaranteed in the Polish Constitution. The article also formulates a political science reflection, which shows a significant effect of the Government's actions on the religious community. Despite the constitutionally guaranteed religious freedom, religious communities in Poland have decided to suspend the exercise of these rights voluntarily.

Keywords: COVID-19; Poland; Polish Constitution; political science of religion; Government of Poland; Muslims; Internet; freedom of religion; religious practices; restrictions; fundamental rights

\section{Introduction}

The coronavirus that causes the disease COVID-19 (Cohen and Normile 2020; Hui et al. 2020; McGill et al. 2021; Gorbalenya 2020; Chen et al. 2020; Challen et al. 2021), started a global pandemic that changed the way of life for all people (Gao and Sai 2020). The pandemic also left its mark in all areas: social, economic, and religious (Sułkowski 2020; Androutsopoulos 2021). Additionally, almost all human life has been transferred to virtual space (Mishra et al. 2020). In fact, those aspects of human life that were highly resistant to technological innovations until recently also had to go online. It was often believed that certain areas of life could not be realized with the Internet's help because they required personal participation. Until the pandemic, religions and their practices seemed to be the greatest strongholds. The traditional "analogue" way of establishing relationships between God, the Absolute, the Supreme Being, and man was defended. Of course, religions are alive; they develop and transform along with the development of civilization globally, adapting to changes in society, and often use technological innovations. For example, reformation, counter-reformation, revival, and innovation are ongoing religious processes and responses to societal and cultural change (Helland 2015). The same happened 
after the invention of the computer and is still occurring in connection with the rapidly expanding network of global Internet connections. Therefore, online research on religiosity has been conducted for many years. However, until the worldwide pandemic outbreak, online religiosity was one of many opportunities to lead a religious life (Helland 2005). It appeared in parallel with the communal, direct participation in religious practices and the individual, personal, sometimes even ascetic realization of religion's principles. Online religion has been the subject of research as an element of socio-cultural changes taking place in the modern world and the development of the network society (Campbell 2012). The inspiration undoubtedly came from reading the fundamental work of Manuel Castells (Castells 1996).

The main research goal is to analyze Muslims' religious attitudes during the COVID-19 pandemic and their reactions to restrictions on free access to religious practices introduced by the Government of Poland. It is vital to implement state ordinances into the everyday religious life of Muslims, including access to prayer rooms in mosques and houses of prayer.

There are currently five Islamic unions and associations registered in Poland: The Muslim Religious Union in the Republic of Poland, The Muslim League in the Republic of Poland, The Association of Islamic Unity, The Ahl-ul-Bayt Islamic Assembly, and The Ahmadiyya Moslem Association (MSWiA 2021; GUS 2020, pp. 249-61). Two of the Muslim organizations in Poland, The Muslim Religious Union in the Republic of Poland and The Muslim League in Poland, are the most numerous and dynamic operating in Poland. The decisions of the heads of Muslim organizations operating in Poland regulated religious practices during the pandemic. An essential aspect of the study is religious leaders' support for the media transmission of the Friday prayer, made available to the faithful primarily via Internet links.

\section{Background}

The first case of the COVID-19 disease in Poland was announced on 4 March 2020. The Republic of Poland's Government introduced the epidemic emergency (Rozp. MZ 2020, p. 433) on 3 December 2020, limiting the number of religious worship participants to 50 people. With the development of the epidemic, on 31 March 2020, the Government announced the state of the epidemic and the number of participants in religious services was estimated at five people (Rozp. RM 2020a, p. 566).

Such rules were introduced because the most effective methods of counteracting the spread of COVID-19 are the behavior of the so-called social distance (safe distance), avoidance of large groups of people, and isolation (Cirrincione et al. 2020; Bedford et al. 2020). These activities significantly changed interpersonal relationships, most of which have moved to virtual reality. Simultaneously, the transfer of all religious practices to online contact has become a challenge, as Islam like every religion is primarily based on a community of believers known as ummah. Being together builds identity and strengthens social ties (Simonsen et al. 2018).

The introduced restrictions on religious practices initiated a social discussion: can the Government limit fundamental civil liberties guaranteed in The Constitution of the Republic of Poland regarding freedom of religion, practice, and manifestation of faith and freedom of conscience? The problem is even more complex, as the Prime Minister of Poland introduced most of the restrictions, orders, and bans related to the pandemic, including those related to religious freedom, based on regulations, not statutes. Such action is inconsistent with the Polish Constitution, which was confirmed by the judgments of the Polish court of law, acquitting the priest of a Catholic parish where there were too many people during the service (Wyrok SR 2020a), as well as other prohibitions and orders limiting civil liberties (Wyrok SR 2020b), which was also finally confirmed by the Supreme Court of The Republic of Poland (Wyrok SN 2021). The Minister of Health believed that churches and other places of worship contribute to the increased transmission of coronavirus and thus are too dangerous for Poles' health and life (Tabaka 2020). 
In the last two weeks of Lent 2020, these events took place at a particular time for Christians preparing for Easter's most important feasts. The introduced quotas for service attendees hit Christians the most: 95\% in Poland (Kościół katolicki w Polsce 2014, p. 14). They could not participate in Holy Week's liturgy, which begins on Palm Sunday, which commemorates Jesus' Triumphal Entry to Jerusalem. The following days of Holy Week remind Catholics of redemption's mystery through the Passion, Death, and Resurrection of Jesus Christ (Duke 2012). Television stations and radio stations, public and commercial, have introduced into their schedule broadcasts of holy masses and Lenten services and live transmission of the Holy Week liturgy from the Vatican (Stachowska 2020). However, it should be emphasized that a program proposal was addressed primarily to Catholics and followers of Protestantism and Orthodoxy, i.e., to Christians (Kurdupski 2020). Nationwide television and radio stations did not provide access to the liturgy to the followers of other great religions present in Poland. Research conducted by CBOS (Public Opinion Research Center) on Poles' religiosity during the pandemic also does not distinguish the problems of representatives of religious minorities with access to spiritual practices (Bożewicz 2020a, 2020b).

Thus, this paper's main objective is to analyze the religious attitudes of Muslims living in Poland and the problems related to the freedom to practice religious worship. The Government of the Republic of Poland's decisions to limit the number of participants in liturgical ceremonies were made on an ongoing basis, often changing within a few hours. At the same time, the Government did not take care of the spiritual sphere of religious minorities as the Polish Episcopate towards Catholics did. Of course, the lack of proper spiritual care for the followers of Islam in Poland may result from divisions within this community and the lack of a typical Muslim community's common position on fundamental issues.

The Islamic unions and associations registered in Poland are based on the provisions of the Constitution of the Republic of Poland and the law guaranteeing freedom of conscience and religion. The Republic of Poland ensures the autonomy of religious associations that can be freely formed. The state relations between the Republic of Poland and various Muslim communities in Poland are good now. Representatives of Muslim unions and associations in Poland take part in the annual meeting organized by the President of Poland with representatives of churches and religious unions present in Poland and national and ethnic minorities (Prezydent 2021). Muslims also join various national initiatives aimed at education in the field of religious and cultural diversity, with particular emphasis on Islam in Poland.

A perfect example is the Night of Temples, organized by religious communities present in Poland. This event has been organized since 2015, initially in Warsaw, and now throughout Poland, always in September, as part of the European Day against Religious Intolerance and Islamophobia, International Day of Peace, and Day of Prayer for Peace. The main message of the Night of Temples is the opportunity to visit the prayer places of other religions, including mosques, and learn about the principles of religion (Noc Świątyń 2020). The Joint Commission of the Government and National and Ethnic Minorities (KPRM 2021), which includes a representative of the Tatar community, works at The Chancellery of the Prime Minister of Poland.

The article's central research hypothesis is to show that the Polish Government's legislative actions undertaken in the context of the COVID-19 pandemic had a noticeable impact on the religious attitudes of Muslims living in Poland. This impact (a) manifested itself in a noticeable limitation of free access to the implementation of religious practices, even though (b) its legal basis may be questioned, and thus (c) the resignation of Muslim communities from constitutionally guaranteed rights was to a large extent a manifestation of their goodwill.

According to the Islamic Calendar, 2020 is 1441/1442 Hijri. At that time, the Muslim community experienced important religious holidays related to the rituals celebrated in mosques and the community of believers and families. From 23 April to 19 May 2020, 
fasting in Ramadan ends with the celebration of Eid al-Fitr's interruption. The second crucial religious event was the annual pilgrimage to Mecca, taking place from 28 July to 3 August 2020, with the Eid al-Adha ending with the most important Muslim holiday. Then 20 August 2020 was celebrated as Islamic New Year, called 1 Muharram 1442, on 29 August 2020 was the Day of Fasting and Penance-Ashura, and on 29 October 2020 was the Birth of the Prophet Mawlid.

The article is divided into two parts. The first part characterizes the Muslim community living in Poland and analyzes the Polish State's attitude on the level of interference in the sphere of religious freedom. It looks for an answer to whether the Government of Poland's encroachment on religious freedom justified by the fight against the COVID-19 pandemic was in accordance with the Constitution. The second, empirical part presents the research methodology and the results of empirical research. It should also be emphasized that the text is interdisciplinary: it combines the perspective of political science of religion and media studies.

\section{Literature Review}

Religion and politics have been intertwined from the earliest times. Fox $(2018$, p. 1) argues that religion was closely related to the politics of every ancient political system: Egypt and Greece, as well as the Mesopotamian, Babylonian, Persian, and Roman empires. The Old Testament explicitly states that religion and the state cannot be separated. Therefore, it is not surprising that an independent scientific discipline has developed: political science of religion, combining elements of policy and religious studies (Potz 2020; Kettell 2015; Gill 2001). Government and politicians' actions left their mark on the followers of various religions in a unique way during the pandemic. The Polish Constitution guarantees the broadly understood freedom of conscience and religion to everyone. Nevertheless, in the face of fear of the scientifically unexplored coronavirus and its negative impact on human health (Johns Hopkins University 2020), the Government issued regulations that directly entered the life of religious communities (Merdjanova 2001). These actions contradicted the provisions of The Constitution of the Republic of Poland (National Assembly 1997, Article 25). The protection of religious freedom concerns all people to whom the state should guarantee equal opportunity to pursue religious practices. In the analyzed situation, this did not happen, because the religious majority received much greater privileges than the communities remaining in the minority (Biuro Komisji Sejmowych 2018).

The issuance of regulations targeting the fundamental civil rights of representatives of religious minorities significantly disturbed Muslims' possibility of worship in Poland. This problem is not new. As early as 2017, Poland's Muslim community asked the prime minister for an appeal to protect Muslims in the country, which the National and Ethnic Minorities Commission rejected. The authors of the appeal stated that political debates reinforced anti-Muslim messages in the media and could escalate xenophobic behavior against Muslims (International Religious Freedom Report for 2018 2019, p. 7). Of course, various initiatives are taken in Poland to integrate the Muslim community with the majority of Christians (Piwko 2011). A model example is the annual Day of Islam organized by the Roman Catholic Church since 2001 to promote peace among religious groups. The event is under the Polish Episcopate Committee for Dialogue's patronage with Non-Christian Religions, and its celebration takes place in many cities: Warsaw, Cracow, Lodz, Bialystok, and Lublin (Topidi 2019). You can even watch the debate on the latest 21st Islamic Day in Poland's Catholic Church on YouTube (Dzień Islamu 2021).

These initiatives, however, are marginal and exist too weakly in the public space, which continues to marginalize the protection and needs of the Muslim community in Poland (Piwko 2010). Additionally, although Polish law seems to be structured appropriately to provide the necessary freedoms to religious minorities, the problem is its practical application. Therefore, more significant efforts are needed to make full and more free exercise of existing rights. It was to ensure these guarantees that the Joint Commission of the Government and National and Ethnic Minorities was established. The Commission 
has a wide range of consultative prerogatives and is an essential link between authorities and representatives of minorities. The most important of them include strengthening intercultural dialogue, setting up the Governance structure for combating discrimination, improvements in education, and more vigorous efforts addressing difficulties experienced by the Roma minority. The Advisory Committee noted the multifaceted nature of Polish authorities' activities to counteract racist, xenophobic, and anti-Semitic attitudes (Godlewska 2014, pp. 69-70).

The subject of religiosity during the COVID-19 pandemic is highly topical and has been taken up by many researchers because the pandemic showed gaps in access to participation in religious services. The results of research in this area were also presented in Religions (Jupowicz-Ginalska et al. 2021; Mazurkiewicz 2021; Cones 2021; Boguszewski et al. 2020; Parish 2020; Sulkowski and Ignatowski 2020). However, it should be emphasized that this research concerned religiosity in general (Park and Kim 2021), with particular emphasis on the Christian milieu in its various denominations. A survey of the Muslim community's mood in Great Britain was conducted by Amin Al-Astewani (2021). On the other hand, no one has conducted similar research on the Polish Muslim community. Before the COVID-19 pandemic, no research was conducted on the subject of Internet access to religious services online. Thus, it can be said that people who, for various reasons, cannot move have been "forgotten". Only the global pandemic, which "locked up" all people in their homes, revealed shortages of access to religious content, and thus new research areas appeared. This article addresses the gaps in the literature.

\subsection{Main Muslim Communities in Poland}

Poland's Muslim community has about 40,000 followers and is very diverse in terms of ethnicity, culture, and confession (Włoch 2009). Various ways of practicing Islam and the heterogeneous interpretation of the message of the Qur'an not only cause problems for believers but also cause many conflicts (Piwko 2015). The time of the pandemic has changed this last aspect somewhat.

The oldest Muslim community in Poland is the Tatars, who settled here in the midfourteenth century. For this reason, the Tatar community has a well-organized administrative and logistic structure. It is also the smallest ethnic Muslim community living in Poland at present, since it has about 5000 people. It should be mentioned that not all ethnic Tatars profess Islam (Szajkowski 1999; Piwko 2017).

The fall of communism in Central and Eastern Europe and numerous geopolitical changes in the world meant that people from Muslim countries began an intensive migration process. For this reason, after 1989, intense changes took place in the structure of the Islamic community in Poland (Stojkow 2018). This was favored by the political transformations taking place in Poland, which took place quickly and efficiently. The Republic of Poland was perceived as a free and safe country (Kubicki 2006). Currently, representatives of the Arab states live here: Algeria, Egypt, Iraq, Yemen, Lebanon, Libya, Tunisia, Syria, Somalia and Sudan, Islamic republics of Afghanistan and Pakistan, Muslim inhabitants of the Caucasus, especially Chechnya, Dagestan and Ingushetia, and European Muslims from Turkey, Bosnia, and Kosovo (Zabek 2012). The foundation that unites various societies is religion, which is a crucial factor informing about belonging to the ummah.

Nevertheless, the multitude of representatives from different countries, often differing in language dialects and everyday habits, significantly affect integrating the Arab community (Górak Sosnowska 2011). With the increase in immigrants from Muslim countries, there has been a "collision" of religious groups following the same religion. Muslim Arabs brought with them Islam in force in their territories, following the principles written in the Koran and passed on by Muhammad. Meanwhile, Islam, professed on the Vistula River, mainly by the Tatars, has undergone many centuries of transformations. Against this background, problems began to multiply at the level of practicing religion, which in turn resulted in a lack of understanding between the followers of Islam living in Poland. 
Currently, Muslims coming from Arab countries constitute the most numerous group in the entire community professing Islam living in Poland.

The third major Muslim social group in Poland is the Turks. Mutual diplomatic relations between Poland and Turkey date back to the beginning of the 15th century, and despite the complicated history, these relations are very good to this day. After the transformation of 1989, Turks willingly invested in Poland, running businesses in the following industries: clothing, catering, and construction. Economic associations POTiAD Business Association (POTiAD n.d.), the Polish-Turkish Chamber of Commerce (PolishTurkish n.d.), and the cultural and educational Danube Institute of Dialogue (Danube n.d.) were also established.

A significant group of followers of Islam in Poland are converts, i.e., people born and raised in Christian families, often Catholic, who, for various reasons, converted to Islam. The popularity of Muhammad's religion has been noticeable for years, primarily in large urban agglomerations, especially among young people (Łojek-Magdziarz 2005).

Such a diverse community of adherents of Islam, in terms of national, ethnic, and linguistic terms, have struggled with numerous problems related to the free practice of religion before the pandemic. The pandemic's time aggravated these problems (Buchowski and Chlewińska 2012). The diversity of countries of origin causes various misunderstandings in everyday life, practicing religion, and adhering to its principles. These elements form the basis of the functioning of the religious community. The lack of unity is interpreted as a split, which is an expression of a betrayal of the true faith in Allah. This lack of unity can cause internal social misunderstandings. Their consequence is the almost immediate perception of the entire Muslim community as people posing a threat to the country's security (Odeh 2004).

The main problem is the tensions within the Muslim community in Poland. There is a confrontation between "old" (Dziekan 2011) and "new" (Górak Sosnowska 2011) Muslims. The "old" incumbents, with a firmly established position in society and the state, are undoubtedly the Tatars, who remain reluctant towards the "new" Muslim communities coming to Poland. This reluctance was particularly evident at the time of the greatest migration crisis in 2015. At that time, the cultural diversity existing between Tatars and newcomers from the Arab-Muslim countries of the Middle East and Africa was emphasized, which is undoubtedly compounded by a significant language barrier and the history of both communities (Urbanek 2015).

It should be emphasized here that the majority of Poles represent this approach to divisions between Muslims in Poland. Even Pope Francis's authority and his statements on Muslim immigrants and refugees did not change the attitudes of Poles toward foreigners who profess Islam. This is because Pope Francis' statements are often questioned in public debate by politicians from the ruling Law and Justice party (PiS). Often, Islam and Muslims in Poland are also presented as a potential terrorist threat, which significantly affects the nationalist mood in Poland (Kuziemski 2016). On this basis, it should be assumed that the state administration deliberately "kept silent" on the problem of the lack of access to the exercise of the Islamic cult in the national media, thus leaving the organization of religious practice only to Muslim communities, even without providing technical support.

\subsection{Religious Freedom in Poland and Government Activities Related to COVID-19}

In the context of the calendar presented above, the inevitable question is to what extent the state has the right to enter the zone of religious freedom. The answer flows directly from the Constitution; one only needs to treat it as a whole and not take out convenient fragments from it. It is one of the fundamental principles of the interpretation of legal acts-one cannot consider individual provisions in isolation from the others; instead, legal norms must be derived from the entire set of provisions relating to a given issue. With this approach, it is clear that the state has no right to interfere in religious freedom: "freedom of conscience and religion shall be ensured to everyone" (National Assembly 1997, Article 53), as in the European Convention on Human Rights: "everyone has the right to freedom of 
thought, conscience, and religion" (National Assembly 1997, Article 9, Section 1). Likewise, the state has no right to interfere with the sphere of human and civil rights in general: "The Republic of Poland shall [...] ensure the freedoms and rights of persons and citizens" (Article 5). The fact that religious freedom is in the Polish Constitution-according to standard international practice (Piechowiak 1996) — treated as one of the human rights is proven by the inclusion of the key Article 53 in the section entitled "Personal freedoms and rights" (Chapter II) and the use of identical (!) phrases in this article to justify the admissibility of restricting the freedom to publicly express religion, as in the article relating to the possibility of limiting freedoms and rights in general (National Assembly 1997, Article 31). The above thesis is also confirmed by the authoritative explanation of the Polish Commissioner for Human Rights: "Freedom of conscience and religion has been included among the freedoms of a personal nature, and the recognition and respect for it by the state and society results from the obligation to protect human dignity" (National Assembly 1997, Article 53-Wolność).

The constitutional guarantees regarding religious freedom are further clarified in the following paragraphs and articles (emphasis A.P. and W.K. here and hereafter):

"Public authorities in the Republic of Poland shall be impartial in matters of personal conviction, whether religious or philosophical, or in relation to outlooks on life, and shall ensure their freedom of expression within public life" (National Assembly 1997, Article 25, Section 2).

"Freedom of religion shall include the freedom to [ . . ] manifest such religion, either individually or collectively, publicly or privately, by worshipping, praying, participating in ceremonies, performing of rites or teaching" (National Assembly 1997, Article 53, Section 2).

Finally, the most critical wording in this aspect: "No one shall be compelled to participate or not participate in religious practices" (National Assembly 1997, Article 53, Section 6).

While emphasizing the certainty of preserving religious freedoms defined in the Constitution, it is crucial to bear in mind the context in which they are found. Its first dimension concerns the genesis of the Constitution, not presented as a result of many years of maturation of democracy in Poland, but written after decades of waiting for the fall of communism and reflecting a compromise that was achieved between widely different political views, from the post-communist left to the radical right. It was captured in beautiful words from the preamble: "We, the Polish Nation-all citizens of the Republic, both those who believe in God as the source of truth, justice, good, and beauty, as well as those not sharing such faith but respecting those universal values as arising from other sources [ ... ] mindful of the bitter experiences of the times when fundamental freedoms and human rights were violated in our Homeland [ . . . ] desiring to guarantee the rights of the citizens for all time ..." ". That is why the Polish "founding fathers" of a modern state, in which believers, Catholics for many years, constitute the dominant majority of society (according to official statistics from that period: over 95\%, Kościół katolicki w Polsce 2014, p. 14), made religious freedom both an undeniable value and a legal record.

The second dimension of the context of the relevant constitutional provisions is of an adaptive nature, necessary in the contemporary, not so romantic world, in which values and rights must, in certain situations, be subject to limitations resulting from the surrounding reality, hence the objection, "any limitation upon the exercise of constitutional freedoms and rights may be imposed only by statute, and only when necessary in a democratic state" (National Assembly 1997, Article 31, Section 3), and further specification, significant in the conditions of the current pandemic, "public authorities shall combat epidemic illnesses" (National Assembly 1997, Article 68, Section 4). One of the instruments provided for such a circumstance is the institution of "appropriate extraordinary measures", in the form of martial law, a state of emergency, or a state of natural disaster (National Assembly 1997, Article 228, Section 1). Then "the degree to which the freedoms and rights of persons and citizens may be subject to limitation for the duration of a period requiring any extraordinary measures shall be established by statute" (National Assembly 1997, Article 228, Section 3). 
Thus, do the latter provisions clear the way for the temporary and/or conditional suspension of constitutional guarantees pf religious freedom understood as one of the human rights in specific circumstances, such as the COVID-19 pandemic? The aforementioned genesis of the Republic of Poland's present Constitution meant that they do not, despite the apparent discrepancies in some formulas. This is because the quoted Article 31 announces that the limitation upon the exercise of constitutional freedoms and rights may be imposed "for the protection of its security or public order, or to protect the natural environment, health, or public morals". However, it then adds: "Such limitations shall not violate the essence of freedoms and rights". This was unquestionably defined earlier as the freedom to manifest one's religion (National Assembly 1997, Article 53).

However, maybe the hypothetical right to limit religious freedoms is included in the provisions on extraordinary measures? It is also not, because Article 233 clearly indicates that in any of the possible extraordinary measures (martial law, a state of emergency, or a state of a natural disaster), violation - generally the dignity of the person (as specified in Article 30), and specifically, in the case of our interest, of conscience and religion (specified in Article 53) is not allowed.

Finally, the observations presented above do not allow, as a peculiar wicket to limitations of rights and freedoms, to treat the undoubtedly unfortunate procedure performed by the authors of the Constitution in the form of the following entry: "Extraordinary measures may be introduced only by regulation, issued upon the basis of statute, and which shall be additionally required to be publicized" (National Assembly 1997, Article 228, Section 2). Taken out of context, it could be understood as a way of imposing any practically arbitrary changes to the provisions of the Constitution, provided that justification for them can be found in an extraordinary situation, to adopt an appropriate law and issue a proper order under it. However, the comprehensive interpretation mentioned at the beginning of this thread of our article definitely does not allow it, pointing to such components of fundamental rights and freedoms, including religious freedom, which cannot be changed without changing the Constitution. They must also not be viewed in conflict with the constitutional message contained in the preamble. Let us add that such a position reflects the achievements of contemporary treatises on the methodology of legal sciences, in which the indispensability of an interpretative, contextual, even hermeneutic approach is indicated.

The interpellations of the Commissioner for Human Rights indicated that the Minister of Health's ordinances, even if they are derived from the acts adopted during the COVID-19 pandemic, also go in this direction without proper legal validation. Already at the time of the outbreak of the pandemic in Poland, in March 2020, he assessed the "restrictions on religious worship" ordered by the Minister of Health as ineffective and open to challenge by ordinary courts. As he wrote: "no executive authority, including the minister competent for health, has, in the light of Art. 53 Section 5 of the Republic of Poland's Constitution, the regulatory capacity to define the limits of the freedom to manifest religion" (Rozp. MZ 2020, p. 433). Similar reservations should therefore be raised with regard to subsequent normative acts of the Government: the so-called COVID acts, ordinances of the Council of Ministers, ordinances of the minister of health, orders and announcements of province governor, etc.

The last question that can and should be asked at this point concerns the possibility of extracting from the legal constructions the wording that could possibly constitute the basis for different legislative actions of the Government during the pandemic against religions other than Catholicism. It is excluded, as evidenced by the following provisions:

- "No one may be compelled by organs of public authority to disclose his philosophy of life, religious convictions or belief" (TheConstitution of the Republic of Poland 1997, Article 53, Section 7).

- "Public authorities in the Republic of Poland shall be impartial in matters of personal conviction, whether religious or philosophical, or in relation to outlooks on life, and shall ensure their freedom of expression within public life" (National Assembly 1997, Article 25, Section 2). 
- "National and ethnic minorities shall have the right to establish educational and cultural institutions, institutions designed to protect religious identity" (National Assembly 1997, Article 35, Section 2).

- "Limitation of the freedoms and rights of persons and citizens only by reason of race, gender, language, faith or lack of it, social origin, ancestry or property shall be prohibited" (National Assembly 1997, Article 233, Section 2).

Above all, let us recall the entry from the preamble to the Constitution: "the Polish Nation-all citizens". Significant help in managing the pandemic in Poland was provided to the Polish Government by TV stations, both the state-owned TVP under the management of the ruling party, as well as commercial stations. As we have shown, the restrictions introduced by the Government aimed at stopping the development of the pandemic in Poland are mostly unconstitutional. In accordance with Polish law, any restrictions on civil liberties must be introduced by a relevant act and fall within the scope allowed by the applicable provisions of the Constitution, which was not the case in the case of the pandemic prohibitions. This position is also upheld by the Supreme Court of The Republic of Poland in its jurisprudence (Wyrok SN 2021). However, due to the intense media coverage, Polish citizens adopted numerous unlawful restrictions as binding. Polish law does not define the terms lockdown and face mask.

\section{Materials and Methods}

The methodology adopted in the research is a socio-legal approach, taking into account the importance of documents issued by politicians regarding restrictions on the exercise of the right to free religious worship. This method enables the extension of the studied phenomena analysis to include a social, theological, and political perspective (Peterson 2003; Tamanaha 2001), the more so as this topic combines aspects of politics and religion (Harris 2007). Moreover, the research used the qualitative method in the form of individual in-depth interviews (Brinkmann 2013; Fox 2009). Their main goal was to identify ways to enable Islam's followers in Poland to participate in religious services during the coronavirus pandemic virtually. The research was aimed at verifying religious activity in the online space. It was also checked to what extent these activities contributed to the maintenance of religious activities among believers and whether they did not cause believers to distance themselves from spirituality.

Individual in-depth interviews with believers of Islam in Poland were conducted between 1 and 28 February 2021, using electronic communication methods and techniques. The date of the study is justified by the fact that almost a year has passed since the start of the COVID-19 pandemic in Poland and the introduction of related restrictions. The interviews were based on a repeatable research scenario, enabling the researchers to ask the respondents additional questions that would allow them to clarify the research problems. The interlocutors answered the questions in various ways they preferred. The largest group of people replied to the questions posed in writing using an e-mail. Some people replied in real-time during the conversation using video communication, and several people replied during the conversation using the Messenger application. Oral statements were recorded and then qualitatively analyzed, as was the material provided in writing. It should be emphasized that some of the respondents' statements are characterized by personal commitment. However, the qualitative research methodology allowed for a critical approach to the problem, resulting from an in-depth insight into the issue. The interviews focused on the following research questions:

- How important are restrictions on free access to mosques for Muslims?

- How does the Muslim community look for other forms of religious activity?

- How do imams and believers view government restrictions?

- What are the dangers of government restrictions on collective religious practice in mosques? The sample of participants in the study is purposeful. It includes twenty people who are representatives of the main Muslim communities living in Poland, belonging to various religious associations, professing Sunni Islam and Shi'ite Islam, 
living in different parts of Poland: in large cities, small towns, and villages. The research group consisted of adults (over 18 years of age), including 13 men and 7 women. The questions were answered by the spiritual leaders of the followers of Islam in Poland, people working in the administration of religious associations or running religious associations, and ordinary believers whose religious activity is limited to practicing Islam. In selecting people taking part in the study, a stratified sample was used because the researchers wanted to know the opinions and different environments of the Muslim community living in Poland (Frankfort-Nachmias et al. 2014). People were not differentiated according to gender, age, level of education, or involvement in religious practices before the pandemic. It should be emphasized that all people participating in the survey have secondary and higher education, obtained in Poland or the countries of origin. All respondents are also professionally active. However, in the selection of the sample, the function performed in religious and Muslim associations was important: mufti, imam, president of the association, director of a cultural center, or people working in secretariats. In the research sample, eighteen people identified with Sunni Islam and two with Shi'ite. Twelve people were representatives of the boards and administration of unions and religious associations with headquarters in major Polish cities: Warsaw, Gdańsk, Poznań, Wrocław, Łódź, Białystok, Lublin, Katowice, Bydgoszcz, Kraków, and Kruszyniany. All these people were involved in the Muslim community's religious and cultural activities in Poland by acting as imams or working in associations and cultural centers. In this group, all respondents were actively involved in the development of Islam in Poland. A significant part of the respondents in this group had education in the field of theology of Islam or Arabic culture and language, acquired outside Poland, and people without theological studies knew Arabic or Turkish. The second griup of the respondents was composed of practicing Muslims, systematically fulfilling the obligations of a believer but not professionally related to the promotion of Islam in Poland and without specialist theological and philological knowledge. As shown above, the social structure of Muslims in Poland is very complex. Therefore, the research sample was attended by representatives of the Tatar and Turkish communities, associated with The Muslim Religious Union in the Republic of Poland, as well as foreigners from various countries living in Poland and converts to Islam, associated with The Muslim League in Poland. However, it should be emphasized that such a division of Muslim affiliation to religious associations is conventional and refers to the general view of the differences in the Muslim community in Poland. There is no rule that one must belong to any of the two religious associations based on citizenship or race. The followers of Islam decide on their own belonging to a selected union (Kaczmarczyk 2016). It should be emphasized at this point that we did not receive an answer from two Muslim centers in Poland. It was a Wrocław Muslim community and a Kraków center of Islamic culture.

The people who were the research sample knew that the researcher conducting the in-depth interviews was independent. They knew the name and surname, and place of work; they also knew for what purpose the research was conducted and where the research results would be published.

Interviews with people responsible for religious formation in the Muslim community revealed technical and financial problems related to religious organizations' activities during the pandemic. The management staff often faces issues, with problems different from those of the followers themselves, who work daily in areas of the economy other than religion. For the followers of Islam, as for other believers in Poland, the biggest problem was the difficult access to worship and limited participation in services. It should be emphasized that the research on Muslim religiosity and religious attitudes among the followers of Islam in Poland during the pandemic was conducted for the first time.

Religious experience can take extreme forms: mysterium tremendum and mysterium fascinosum, about which Rudolf Otto (2017) wrote in his work The Idea of the Holy. How- 
ever, it is always a relationship with the sensus Numinis, as Otto defines God or another Holiness that man worships, respects, and pays due veneration. Religious Studies take to five dimensions of religion: intellectual (knowledge or cognitive aspects of religiosity), ideological (beliefs), ritualistic (religious practices), experiential (the feelings and emotions caused by religious experiences), and consequential (religiosity's consequences for an individual's daily functioning) (Glock and Stark 1965). These dimensions became the focus of research on Muslims' religious attitudes during a pandemic towards government actions.

\section{Results, Analysis, and Discussion}

Government restrictions on one of the fundamental freedoms of man, which is the freedom to profess religion, had a significant impact on all believers, not only in Poland but also worldwide. Closing worship places often provoked negative reactions from the faithful, causing them to question the introduced rules (Kowalczyk et al. 2020). The introduced restrictions aimed to inhibit the transmission of SARS-CoV-2 infections, especially in large groups of people, the more so because in the initial phase of the pandemic in South Korea, the greatest number of infections occurred during the religious practices of the Shincheonji Church of Jesus in Daegu (Wildman and Bulbulia 2020). In the Islamic world, the epicenter of coronavirus infections was Iran's Qom, the holy city of Shi'ites and their pilgrimage destination, to which crowds of pilgrims flocked in February 2020. The Shycikh clerical regime downplayed the threat, claiming that entire cities' isolation and quarantine are outdated and ineffective. The head of the sanctuary in Qom, Mohammad Saeedi, called on pilgrims to make pilgrimages, claiming that the holy sanctuary was a place of healing and that coming to it would cure not only spiritual but also physical diseases (Wright 2021).

\subsection{Islamic Religious Leaders against State Sanitary Rules}

For the health of the faithful community, The Muslim Religious Union in the Republic of Poland issued a message on the limitation of Friday and collective prayers in mosques on 12 March 2020. It encouraged the faithful to stay at home and say individual prayers (Miśkiewicz 2020). A similar statement regarding the closure of all mosques and cultural centers was issued by the chairman of The Muslim League in Poland (Chadid 2020). At this point, it should be emphasized that in Islam, there is no obligation to attend a mosque for prayer (Al-Astewani 2021). However, a mosque is an extremely important religious, social, and communal center for all believers, in which the bond between believers is strengthened. Therefore, the Muslim leaders in Poland did not issue dispensations from participation in the services. In the initial phase of the pandemic development, in March and April 2020, The Muslim Religious Union in the Republic of Poland also applied other cult restrictions to its members according to state regulations. The number of participants in services, weddings, and funerals was limited to five people. However, along with the government changes regarding the number of participants in religious worship, modifications were introduced: increasing the number of believers to 50 people, then one person per $15 \mathrm{~m}^{2}$ (Rozp. RM 2020b, p. 697). These restrictions continued to restrict believers' access to places of worship significantly.

Muslim leaders, muftis and imams, noticing problems with access to religious content in national media, intensified religious activity on social media. The Muslim Religious Union in the Republic of Poland in June 2020 launched a channel on YouTube (MZR 2020), which hosts Khutbahs, the official religious sermon in Islam. At the time of writing, the channel shared 61 videos, many of them Khutbahs, but also posted a religious awareness message discussing Laylat al-Raghaib (Noc al-raga'ib 2021), one of the Five Blessed Nights in Islam.

The representative of the Muslim Religious Union in the Republic of Poland said in an interview that during the period of the restrictions on the number of participants in the services, sanitary recommendations were observed inside mosques, and several or a dozen people participated in collective prayers, depending on the size of the prayer room. On the other hand, the faithful gathered around the mosques, outside. However, this rule did not 
apply everywhere. A Muslim woman from Wrocław said: "our Muslim prayer house in Wrocław has been closed since the beginning of the pandemic, i.e., from March 2020".

\subsection{Individual Religious Spiritual Ministry}

The personal spiritual ministry of the imams was available throughout the entire pandemic period. The faithful could contact the imam by phone or e-mail, as well as arrange an individual interview. Funerals were performed as usual, albeit with a limited number of mourners. People participating in the research interviews emphasized that telephone and e-mail contact increased significantly during the lockdown, also between the followers. It shows how important an element of interpersonal relations is in establishing and maintaining a community.

The Muslim League in Poland manages mosques and Muslim centers in major Polish cities (Warsaw, Poznań, Wrocław, Lublin, Łódź, Kraków, Katowice). From the beginning of the pandemic, they have all been closed to the faithful, and they are still so. The only exception is the mosque in Warsaw, where from July 2020, Muslims can pray individually. The mosque is open, but there are no prayers and community services on Fridays. Several people come to the mosque every day. The Imam of the Muslim League in Poland stressed that although community prayer in a mosque is especially valuable in Islam, it should be performed individually at home in times of illness or epidemic. The community's health is a greater good than the fulfilment of recommendations regarding religious worship exercise. As with The Muslim Religious Union in the Republic of Poland, imams and Muslim communities' administration work normally. The faithful can arrange interviews individually, and they also have access to receive certificates related to a wedding or funeral. They can also benefit from spiritual support in person or through remote communication applications, such as Zoom, Skype, or Google Meet. In Poland, the Muslim League runs weekly, usually on Saturday or Sunday, online broadcasts of religion lessons for children and adults. These lessons last $1.5 \mathrm{~h}$. On the Facebook profile, videos are also published on religious topics related to current affairs, such as patience, piety, power, and God's will (Islam Poland 2020). The faithful themselves strive to deepen their religiosity by searching for information on the Internet and watching films about Islam. It should be emphasized at this point that The Muslim League in Poland associates with mainly Muslim foreigners who came to Poland from various Islamic countries. Their knowledge of the Arabic language is much better; it is often their mother tongue, compared to the Muslim Tatars who have lived in Poland for hundreds of years. Probably, for this reason, the Polish offer of The Muslim League in Poland, in the field of expanding religious news, addressed to members of The Muslim League in Poland, is not as extensive as it is in The Muslim Religious Union in the Republic of Poland. The imam of The Muslim League in Poland emphasized the importance of direct contacts between the faithful and the imam, which is difficult to implement during an epidemic threat. Therefore, The Muslim League in Poland made every effort to preserve and uphold the integrity of the community of believers, the ummah, among themselves, using the means of distance communication.

\subsection{Attitudes of Muslims towards Government Restrictions of Religious Freedoms}

Muslims are less understanding about government restrictions. Like most people in the world, they are tired of constant information about COVID-19 and bored with new lockdowns forcing people to carry out all their activities, including religious practices, via the Internet. What a few months earlier seemed a convenient solution, i.e., access to religious practices without leaving home, has now become a curse and a kind of prison. People are social creatures and need a direct relationship with others. Hence, the boredom of internet religion and being online is progressing. A Muslim from Gdańsk stated: "Internet service is convenient, you do not have to leave the house, but I already miss a normal life, I am tired of restrictions and prohibitions". In another mosque in Warsaw, a maximum of $25 \%$ of the faithful may gather for common prayer. Others attend online services. However, the imam pointed out that the religious message reached $30 \%$ of the faithful in this way. 
The group of respondents consisting of Muslims not professionally related to religious activities pointed to the positive aspect of the remote mode, almost unlimited opportunities to participate in religion lessons and seminars dealing with Islam's issues, organized worldwide. Before the pandemic, many events of this kind were not broadcast online. Maciej from Łódź: "For me, the pandemic in the religious dimension turned out to be a good time. I had much more time for individual reflection on spiritual matters, I functioned slower than before the pandemic, I was able to participate in religious seminars all over the world because I know English".

The conducted research has diagnosed the problems that Muslims in Poland have to face during the pandemic. A gradual move away from each other was observed. This distance is not about the sanitary distance, which is intended to stop the transmission of the virus. Being in isolation and limiting social contacts with the community, including the almost complete closure of mosques, resulted in increasing loneliness and a sense of alienation. Symptoms similar to depression and PTSD are also increasing, associated with constant concern for the health of one's own and loved ones (Babicki et al. 2021). This problem is particularly acute for foreigners who, staying in the community of believers, coped with adapting to a new country much easier. An additional difficulty is a significantly limited possibility of travelling worldwide and the lack of personal contact with family. Such limitations strengthen selfishness, which may become a significant obstacle in implementing interreligious projects in the future. Government anti-pandemic restrictions have significantly affected the activities of foundations that promote religious and cultural dialogue between Christians and Muslims. People involved in the Danube Institute of Dialogue activities indicated in the study that the prohibition of interpersonal contacts practically prevents cooperation in this area. An employee of a foundation promoting Islam's culture said: "People are moving away from each other for fear of contamination. They stopped leaving their homes, so there is a shortage of volunteers on whom our activities are based. We make every effort to support seniors of various faiths, not only Muslims. Some of us were shopping for elderly people, we sent Christmas gift packages to our Christian friends by couriers". Effective and fruitful dialogue must be based on a direct encounter between the followers of different religions. A personal meeting is an essential element of getting to know each other. Of course, foundations and associations promoting these ideas make every effort to ensure that the current work is not destroyed. However, online contact is no substitute for a personal experience of meeting and dining together at the same table.

The most frequently indicated methods of solving the problems that arose were to restore the whole possibility of communal prayer in mosques and prayer halls while maintaining the basic hygiene rules. A Muslim from Poznan: "I would like it to be as it used to be. In the mosque, we take care of hygiene anyway, we do ablution, you can stand at appropriate distances from each other. The possibility of getting infected is minimal, similar to the one in the store".

Such action is particularly important for children and young people because too long a break in the traditional way of praying and personal participation in church services causes negative habits, first of all, laziness and boredom (Kim 2021). The laziness will cause the believer to ask questions: why should I go to the mosque service when I can attend a laptop screen? Too-long or theologically difficult chutba will be a reason for distraction and focusing on something else. Religious practices may become one of the many TV programs available in the video-on-demand system (Gorman 2015; Recio-Román et al. 2019). It has been known for years that prolonged lockdown is a severe threat not only to social relations but also to the spiritual development of a person, regardless of religion (Koenig 2012; Jawaid 2014). In addition, an essential problem in the operation of mosques and prayer houses and centers of Muslim culture, as in the case of other churches and religious associations, is the decrease in donations made by the faithful for the maintenance and operation of places of worship. The decrease in donation payments is closely related not only to restrictions related to access to places of prayer but also restrictions related to 
the performance of professional work by the followers of Islam. At this point, it should be emphasized that a significant number of Muslims, foreigners living in Poland, work in the catering industry or run their own business, strictly dependent on the number of customers and the wealth of their wallets. The decrease in the sum of donations significantly affects the difficulties in maintaining the cult buildings: bills for heating, electricity, water, and other obligatory tributes.

The pandemic time is also negatively perceived by the representatives of the minority current of Islam, which is Shi'ism. In Poland, the Shi'ite community is associated with the Muslim Unity Association and has about 50 members (GUS 2020). This community does not have its own mosque, so Friday prayers were held together with the Sunnis. The closure of mosques by facility administrators made it impossible for Shi'ites to pray together. There are also no online prayers. Therefore, the Shi'ite community in Poland sees lockdown as a powerful threat to religiosity. A Shi'ite Pole who wants to remain anonymous: "We are a small community, we do not have our own mosque, because we cannot afford it. We use a Sunni mosque where a foreigner presides. During the pandemic, few people come to pray, there is fear that youth will turn away from religion or convert to Sunni Islam." For this reason, the time of the pandemic was used by the Muslim Unity Association for intensive work related to publishing activities, which would at least partially compensate for the deficiencies in organized religious life. Four books were published in 2020: (Rocznik Muzułmański 2020), Esencja Tauhidu: nauki Ahl ul-Bejt (Radhawi 2020), Wokół roku 1920 (Pelica 2020), and Al-Chisaal (Sheikh Saduq 2020).

The reduction of government restrictions in place of worship meant that some mosques in Poland returned to performing community prayers. This is what happens in Gdańsk. However, very few people come to common services. This situation is related to the fact that there are many advanced Tatars in the Muslim community in Gdańsk. Seniors, out of concern for their own health, avoid numerous groups of people-usually, the faithful gather for prayer on Friday or Sunday. The Muslim community in Gdańsk also did not broadcast services online.

An interesting result in the conducted research gave an answer to the question: do imams perceive the threats to faith related to the ban on practicing religion collectively in mosques? Imams do not see the dangers; they believe that every believer knows how to act for the religious practice to be complete and fruitful. The imam from Gdańsk: "I do not see any threats to the faith practiced at home without coming to the mosque. People know that there is a risk of contracting a serious disease, so they stay at home for their own sake." The imam gave a similar answer from Poznań: "The faithful need physical contact with the mosque and other faithful, unfortunately in this situation it is very limited, so we try, if possible, to use the Internet or talk to the faithful individually, taking special precautions. We create a substitute for integrity among ourselves; therefore, there is no place here for a threat to the stability of faith".

On the other hand, a completely different answer was given by Muslims who see restrictions on access to the mosque as a significant threat to religion and society. A Muslim woman from Kruszyniany: "I couldn't participate in prayers in the mosque and in the community during Ramadan, and this is a very important time for me. Our community is scattered all over Poland, and holidays are a time not only for prayer but also for meetings. The pandemic has prevented us from seeing loved ones".

People participating in the study did not express critical opinions towards the Islamic clerical authorities in Poland due to the lack of transmission of services or their limited availability. The respondents emphasized the limitless possibilities of online resources that can be used if someone needs to deepen their religious life. An Iraqi from Katowice: "I have lived in Poland for many years and have always participated in community prayers in Katowice, but now during the pandemic, I have discovered the unexplored resources of the Internet, thanks to which I have deepened my knowledge of religion". 


\section{Conclusions}

The analysis presented above is a review of Muslims' religious attitudes in Poland during the COVID-19 pandemic towards the legislative actions of the Government of the Republic of Poland, with particular emphasis on the prohibitions and restrictions introduced in the field of religious practices. This review has highlighted the severe problems that had to be, and often still have to be, faced by the followers of Islam in Poland. As a result of the conducted research, it can first be concluded that the basic dimensions of religion have not been fully satisfied due to the introduced government restrictions. The intellectual dimension was fully satisfied because the knowledge and cognitive aspects of religiosity were unlimited. Each believer could study religion on his own. It was similar to ideological aspects, i.e., with beliefs. Despite restrictions on access to community prayer sites, Muslims could and still can practice their religion individually. These rights have not been abolished.

On the other hand, three other vital aspects of religiosity were not satisfied, namely: religious practice related to the ritual-going to the mosque, along with the entire ritual of preparation for joint prayer, under the guidance of the imam. The ritual was limited to individual prayer only. Thus, experiential aspects could not be fully satisfied, and so the feelings and emotions caused by religious experiences. The religious experience was significantly impoverished, and in the case of the experience of the pilgrimage to Mecca, it was completely impossible due to the restrictions on movement and travel. Muslims, like the followers of other religions, had limited opportunities for family gatherings during Muslim holidays. Finally, the fifth aspect of religion that has been seriously affected during the COVID-19 pandemic is consequential-religiosity's consequences for an individual's daily functioning.

The second important element emerging from the conducted research is the diversified religious attitudes of Muslims in Poland during the COVID-19 pandemic towards the Polish Government's legislative activities. The religious leaders feel that they have made every effort not to leave the faithful without spiritual support, and they supported their pastoral activity with numerous pieces of evidence. On the other hand, the followers of Islam were much more critical of the Government's actions, pointing primarily to discouragement and boredom, being forced to stay in isolation, and the lack of opportunities to meet on a religious and social level. It has been emphasized many times that a visit to a mosque for prayer is not only the fulfillment of religious obligations, but also the opportunity to meet in person with other believers, and for foreigners, the opportunity to talk in their native language. Thus, it should be stated that the research hypothesis put forward in the introduction to this article regarding the legislative activities of the Polish Government during the COVID-19 pandemic on the religious life of Muslims in Poland has been verified and validated.

From the beginning of the pandemic in Poland, Muslims have had significantly more difficult access to religious practices. Some mosques and prayer houses are closed for fear of coronavirus infection, while others are functioning to a limited extent. This was because both main Muslim religious associations operating in Poland complied with the Government's recommendations to counteract the pandemic's development. This attitude of the administration that governs Islam in Poland is not surprising, because Islam in Poland is not only a minority religion but also a marginal one. However, it should be clearly emphasized, it is deeply embedded in the history of Poland. However, social aversion to Islam causes religious leaders to avoid any situation that would lead to an escalation of hostility towards the followers of Islam. In its activities, the Muslim community in Poland also aims to avoid conflicts with the rest of Polish society.

For this reason, Muslims do not want to be accused of disobeying the Polish authorities. Muslim overlords obeyed all state regulations in their environment, often to the detriment of the followers of Islam. Islamic imams operating in Poland did not demand that the Polish authorities respect the fundamental civil right, which is the freedom to profess one's religion. In the absence of resistance from the public, the Republic of Poland's 
administration freely introduced various restrictions that threatened citizens' fundamental freedoms. The introduction of restrictions against basic civil liberties, including freedom of religion and conscience, was supported by intense media coverage. Television stations, state-owned TVP and commercial TVN and Polsat, as well as nationwide radio stations and leading Internet portals, constantly informed viewers about the increase in infections, the number of patients, and deaths. The dramatic media message easily reached citizens, reinforcing the belief that the introduced restrictions were right, even if they were not in line with the applicable law regulated by the Republic of Poland's Constitution.

Of course, it should be noted that Islam's teaching, which clearly obliges its faithful, that you must not endanger yourself and endanger others, has significant significance for the above-presented religious attitudes. This indication, derived from the teachings of Islam, has become the basis for many Muslims' adoptions of the limitations resulting from the pandemic. Additionally, although the population is tired of the ongoing restrictions, they can understand the necessity of introducing them. However, the Polish Muslim community sees the risks associated with the too-long separation of religious practices from places of prayer, mosques and prayer halls, especially among children and young people. There are serious concerns about young people's distancing themselves from institutionalized religious life, favoring online religiosity, if the pandemic restrictions continue for another year.

Author Contributions: Conceptualization: W.K. and A.M.P.; methodology: W.K. and A.M.P.; formal analysis W.K. and A.M.P.; resources: W.K. and A.M.P.; writing (original draft preparation): W.K. and A.M.P.; writing (review and editing): W.K. and A.M.P.; supervision: W.K. and A.M.P. All authors have read and agreed to the published version of the manuscript.

Funding: This research received funding from a grant from The Ministry of Science and Higher Education Republic of Poland 2021. The APC was funded by The Ministry of Science and Higher Education Republic of Poland 2021.

Institutional Review Board Statement: Not applicable.

Informed Consent Statement: Not applicable.

Data Availability Statement: Not applicable.

Acknowledgments: The authors thank representatives of Muslim communities for participating in the study.

Conflicts of Interest: The authors declare no conflict of interest.

\section{References}

Al-Astewani, Amin. 2021. To Open or Close? COVID-19, Mosques and the Role of Religious Authority within the British Muslim Community: A Socio-Legal Analysis. Religions 12: 11. [CrossRef]

Androutsopoulos, George. 2021. The Right of Religious Freedom in Light of the Coronavirus Pandemic: The Greek Case. Laws 10: 14. [CrossRef]

Babicki, Mateusz, Ilona Szewczykowska, and Agnieszka Mastalerz-Migas. 2021. Mental Health in the Era of the Second Wave of SARS-CoV-2: A Cross-Sectional Study Based on an Online Survey among Online Respondents in Poland. International Journal of Environmental Research and Public Health 18: 2522. [CrossRef]

Bedford, Juliet, Delia Enria, Johan Giesecke, David L. Heymann, Chikwe Ihekweazu, Gary Kobinger, H. Clifford Lane, Ziad Memish, Myoung-don Oh, Amadou Alpha Sall, and et al. 2020. COVID-19: Towards controlling of a pandemic. The Lancet 395: 1015-18. [CrossRef]

Biuro Komisji Sejmowych. 2018. Petny Zapis Przebiegu Posiedzenia Komisji Mniejszości Narodowych i Etnicznych, nr 74, z Dnia 2 Lipca 2018. Warsaw: Sejm RP.

Boguszewski, Rafał, Marta Makowska, Marta Bożewicz, and Monika Podkowińska. 2020. The COVID-19 Pandemic's Impact on Religiosity in Poland. Religions 11: 646. [CrossRef]

Bożewicz, Marta. 2020a. Religijność Polaków w Czasie Pandemii. Warszawa: CBOS.

Bożewicz, Marta. 2020b. Wpływ Pandemii na Religijność Polaków. Warszawa: CBOS.

Brinkmann, Svend. 2013. Conversation as Research: Philosophies of the Interview. Counterpoints 354: $149-67$. 
Buchowski, Michał, and Katarzyna Chlewińska. 2012. Tolerance of Cultural Diversity in Poland and Its Limitation, ACCEPT Pluralism, 2012/34 Country Synthesis Report. Available online: http://cadmus.eui.eu/bitstream/handle/1814/24381/ACCEPT_WP5_201 2_34_Country-synthesis-report_Poland.pdf (accessed on 17 March 2021).

Campbell, Heidi. 2012. Religion and the Internet: A microcosm for studying Internet trends and implications. New Media E Society 15: 680-94.

Castells, Manuel. 1996. The Information Age: Economy, Society and Culture. The Rise of the Network Society. Cambridge: Blackwell.

Chadid, Youssef. 2020. Komunikat Ligi Muzułmańskiej w RP w sprawie zamknięcia Centrów Muzułmańskich zarządzanych przez LM w RP w obliczu pandemii koronawirusa. Available online: http://islam.info.pl/komunikat-ligi-muzulmanskiej-w-rp/ (accessed on 17 March 2021).

Challen, Robert, Ellen Brooks-Pollock, Jonathan M. Read, Louise Dyson, Krasimira Tsaneva-Atanasova, and Leon Danon. 2021. Risk of mortality in patients infected with SARS-CoV-2 variant of concern 202012/1: Matched cohort study. The BMJ 372: n579. [CrossRef]

Chen, Nanshan, Min Zhou, Xuan Dong, Jieming Qu, Fengyun Gong, Yang Han, Yang Qiu, Jingli Wang, Ying Liu, Yuan Wei, and et al. 2020. Epidemiological and clinical characteristics of 99 cases of 2019 novel coronavirus pneumonia in Wuhan, China: A descriptive study. Lancet 395: 507-13. [CrossRef]

Cirrincione, Luigi, Fulvio Plescia, Caterina Ledda, Venerando Rapisarda, Daniela Martorana, Raluca Emilia Moldovan, Kelly Theodoridou, and Emanuele Cannizzaro. 2020. COVID-19 Pandemic: Prevention and Protection Measures to Be Adopted at the Workplace. Sustainability 12: 3603. [CrossRef]

Cohen, Jon, and Dennis Normile. 2020. New SARS-like virus in China triggers alarm. Science 367: 234-35. [CrossRef] [PubMed]

Cones, Bryan. 2021. Essential Workers, Essential Services? Leitourgia in Light of Lockdown. Religions 12: 101. [CrossRef]

Danube. n.d. Official Website of the Institiute. Available online: https:/ /www.dialoginstytut.pl (accessed on 17 March 2021).

Duke, Will. 2012. Passion Week. A Study of the Events Surrounding Jesus' Crucifixion and Their Timing. Rome: WD Publisher.

Dziekan, Marek. 2011. History and Culture of Polish Tatars. In Muslims in Poland and Eastern Europe: Widening the European Discourse on Islam. Edited by Katarzyna Górak Sosnowska. Warsawa: University of Warsaw, p. 29.

Dzień Islamu. 2021. XXI Dzień Islamu w Kościele Katolickim w Polsce. Available online: https://youtu.be/GRpmAfvTL-0, opublikowane26stycznia2021r (accessed on 19 March 2021).

Fox, Nick. 2009. Using Interviews in a Research Project. Nottingham: The NIHR RDS for the East Midlands.

Fox, Jonathan. 2018. An Introduction to Religion and Politics. Theory and Practice. London and New York: Routledge.

Frankfort-Nachmias, Chava, David Nachmias, and Jack DeWaard. 2014. Research Methods in the Social Sciences. London: Worth Publishing Ltd.

Gao, Grace, and Linna Sai. 2020. Towards a 'virtual' world: Social isolation and struggles during the COVID-19 pandemic as single women living alone. Gender, Work E Organization 27: 754-62.

Gill, Anthony. 2001. Religion and Comparative Politics. Annual Review 4: 117-38.

Glock, Charles, and Rodney Stark. 1965. Religion and Society in Tension. Chicago: Rand McNally.

Godlewska, Ewa. 2014. National and Ethnic Minorities in Poland in the opinions of The Advisory Committee of The Council of Europe. Przeglad Zachodni 2: 65-75.

Górak Sosnowska, Katarzyna. 2011. Muslims in Europe: Diferent communities, one discourse? Adding the Central and Eastern European perspective. In Muslims in Poland and Eastern Europe: Widening the European Discourse on Islam. Edited by Katarzyna Górak Sosnowska. Warsawa: University of Warsaw, pp. 12-26.

Gorbalenya, Alexander, and et al. 2020. The species Severe acute respiratory syndrome-related coronavirus: Classifying 2019-nCoV and naming it SARS-CoV-2. Nature Microbiology 5: 536-44.

Gorman, Carma. 2015. Religion on Demand: Faith-based Design. Design and Culture 1: 9-22. [CrossRef]

GUS. 2020. Wyznania Religijne w Polsce w Latach 2015-2018. Warszawa: GUS.

Harris, Phil. 2007. Law in Context: An Introduction to Law. Cambridge: Cambridge University Press.

Helland, Christopher. 2005. Online Religion as Lived Religion. Methodological issues in the study of religious participation on the Internet. Heidelberg Journal of Religions on the Internet 1: 8-24.

Helland, Christopher. 2015. Virtual Religion: A Case Study of Virtual Tibet. Scholarly Research Reviews 2: 2-24.

Hui, David S., Esam I. Azhar, Tariq A. Madani, Francine Ntoumi, Richard Kock, Osman Dar, Giuseppe Ippolito, Christian Drosten, Alimuddin Zumla, Eskild Petersen, and et al. 2020. The continuing 2019-nCoV epidemic threat of novel coronaviruses to global health-The latest 2019 novel coronavirus outbreak in Wuhan, China. International Journal of Infectious Diseases 91: 264-66. [CrossRef]

International Religious Freedom Report for 2018. 2019. Poland 2018 International Religious Freedom Report. Washington: Bureau of Democracy, Human Rights, and Labor.

Islam Poland. 2020. Available online: https:/ /www.facebook.com/Islam.Poland (accessed on 17 March 2021).

Jawaid, Hena. 2014. Impact of Religion/Spirituality on Health: What are the Evidences? Journal of Psychiatry 17: 6.

Johns Hopkins University. 2020. Coronavirus Resource Center. Available online: https:/ / coronavirus.jhu.edu/map.html (accessed on 17 March 2020). 
Jupowicz-Ginalska, Anna, Marcin Szewczyk, Andrzej Kiciński, Barbara Przywara, and Andrzej Adamski. 2021. Dispensation and Liturgy Mediated as an Answer to COVID-19 Restrictions: Empirical Study Based on Polish Online Press Narration. Religions 12: 127. [CrossRef]

Kaczmarczyk, Rafał. 2016. Status prawny i faktyczny muzułmańskich związków wyznaniowych w Polsce. Studia z Prawa Wyznaniowego 19: 263-87. [CrossRef]

Kettell, Steven. 2015. Do We Need a 'Political Science of Religion'? Political Studies Review 14: 210-22. [CrossRef]

Kim, Hyun-Sook. 2021. Beyond Doubt and Uncertainty: Religious Education for a Post-COVID-19 World. Religious Education 116: 41-52. [CrossRef]

Koenig, Harold. 2012. Religion, Spirituality, and Health: The Research and Clinical Implications. Psychiatry 8: 278730. [CrossRef]

Kościół katolicki w Polsce. 2014. Rocznik Statystyczny. Warszawa: Zakład Wydawnictw Statystycznych.

Kowalczyk, Oliwia, Krzysztof Roszkowski, Xavier Montane, Wojciech Pawliszak, Bartosz Tylkowski, and Anna Bajek. 2020. Religion and Faith Perception in a Pandemic of COVID-19. Journal of Religion and Health 59: 2671-77. [CrossRef]

KPRM. 2021. Komisja Wspólna Rządu i Mniejszości Narodowych i Etnicznych. Available online: https://www.gov.pl/web/premier/ komisje-wspolne (accessed on 2 May 2021).

Kubicki, Paweł. 2006. Społeczność muzułmańska w Polsce. In Islam i Obywatelskość w Europie. Edited by Katarzyna Górak-Sosnowska and Konrad Pędziwiatr. Warszawa: Arabia.pl, pp. 130-2.

Kurdupski, Michał. 2020. Duży Wzrost Oglądalności mszy Świętych w Telewizji. Available online: https:/ /www.wirtualnemedia.pl/ artykul/duzy-wzrost-ogladalnosci-mszy-swietych-w-telewizji-analiza (accessed on 17 March 2021).

Kuziemski, Maciej. 2016. Poland Refuses to Accept Refugees- but Is Happy to Accept Other Countries' Hospitality. Quartz. March 25. Available online: http:/ / qz.com/647663/poland-refuses-to-accept-refugees-but-its-happyto-accept-other-countries-hospitality (accessed on 17 March 2021).

Łojek-Magdziarz, Aleksandra. 2005. Nowi polscy muzułmanie-Fundamentaliści czy mistycy? Czas Kultury 6: 7-9.

Mazurkiewicz, Piotr. 2021. Religious Freedom in the Time of the Pandemic. Religions 12: 103. [CrossRef]

McGill, Andrew R., Roukiah Kahlil, Rinku Dutta, Ryan Green, Mark Howell, Subhra Mohapatra, and Shyam S. Mohapatra. 2021. SARS-CoV-2 Immuno-Pathogenesis and Potential for DiverseVaccines and Therapies: Opportunities and Challenges. Infectious Disease Reports 13: 102-25. [CrossRef]

Merdjanova, Ina. 2001. Religious Libert, New Religion Movements and Traditional Christian Churches in Eastern Europe. Religion, State and Society 29: 265-304. [CrossRef]

Mishra, Lokanath, Tushar Gupta, and Abha Shree. 2020. Online teaching-learning in higher education during lockdown period of COVID-19 pandemic. Internetional Journal of Educational Research Open 1: 1-8. [CrossRef]

Miśkiewicz, Tomasz. 2020. Oświadczenie Najwyższego Kolegium Muzułmańskiego Związku Religijnego w RP. Available online: http://mzr.pl/oswiadczenie-najwyzszego-kolegium-muzulmanskiego-muzulmanskiego-zwiazku-religijnego-wrzeczypospolitej-polskiej/ (accessed on 17 March 2021).

MSWiA. 2021. Rejestr kościołów i innych związków wyznaniowych 30 March 2021. Available online: https://www.gov.pl/web/ mswia/rejestr-kosciolow-i-innych-zwiazkow-wyznaniowych (accessed on 2 May 2021).

MZR. 2020. Official Website of the Channel. Available online: https:/ /www.youtube.com/c/MZRwRP/featured (accessed on 17 March 2021).

National Assembly. 1997. The Constitution of The Republic of Poland. Warsaw: Wydawnictwo Sejmowe.

Noc al-raga'ib. 2021. Available online: https:/ / www.youtube.com/watch?v=JR6Bz_SyceM\&t=29s (accessed on 17 March 2021).

Noc Światyń. 2020. Available online: http:/ / nocswiatyn.eu.org/index.php?s=program\&f=program-by-date (accessed on 2 May 2021).

Odeh, Amira. 2004. Islam po polsku. Integracja Europejska 52: 88.

Otto, Rudolf. 2017. The Idea of Holy. Oxford: University Press.

Parish, Helen. 2020. The Absence of Presence and the Presence of Absence: Social Distancing, Sacraments, and the Virtual Religious Community during the COVID-19 Pandemic. Religions 11: 276. [CrossRef]

Park, Cheonghwan, and Kyungrae Kim. 2021. Covid-19 and Korean Buddhism: Assessing the Impact of South Korea's Coronavirus Epidemic on the Future of Its Buddhist Community. Religions 12: 147. [CrossRef]

Pelica, Grzegorz. 2020. Wokót Roku 1920. Warszawa: Stowarzyszenie Jedności Muzułmańskiej.

Peterson, Kerry. 2003. Socio-Legality: An Odyssey of Ideas and Context. Alexandria: The Federation Press.

Piechowiak, Marek. 1996. Wolność religijna-aspekty filozoficznoprawne. Toruński Rocznik Praw Człowieka i Pokoju 1994-1995 3: 7-21.

Piwko, Aldona Maria. 2010. Dialog religijny chrześcijan i muzułmanów w Polsce. Instytucje kościelne działające na rzecz porozumienia międzyreligijnego. Annales Missiologici Posnanienses 17: 137-50. [CrossRef]

Piwko, Aldona Maria. 2011. Dialog Kościoła katolickiego z islamem w Polsce. Collectanea Theologica 81: 149-58.

Piwko, Aldona Maria. 2015. Recepcja Islamu w Polsce-synteza. Warszawa: Instytut Dialogu Kultury i Religii.

Piwko, Aldona Maria. 2017. Związki i stowarzyszenia tatarskie w Polsce. Nurt SVD 2: 10-25.

Polish-Turkish. n.d. Official Website of the Association. Available online: http:/ / www.ptcoc.eu (accessed on 17 March 2021).

POTiAD. n.d. Official Website of the Association. Available online: http:/ / potiad.org (accessed on 17 March 2021).

Potz, Maciej. 2020. Political Science of Religion. Theorizing the Political Role of Religion. Łódź: University of Łódź. 
Prezydent. 2021. Spotkanie z przedstawicielami kościołów i związków wyznaniowych oraz mniejszości narodowych i etnicznych w Polsce. Available online: https://www.prezydent.pl/aktualnosci/wydarzenia/art,2059, spotkanie-z-przedstawicielamikosciolow-i-zwiazkow-wyznaniowych-oraz-mniejszosci-narodowych-i-etnicznych-obecnych-w-polsce.html (accessed on 2 May 2021).

Radhawi, Sayyid. 2020. Esencja Tauhidu: Nauki Ahl ul-Bejt. Warszawa: Stowarzyszenie Jedności Muzułmańskiej.

Recio-Román, Almudena, Manuel Recio-Menéndez, and María Victoria Román-González. 2019. Religion and Innovation in Europe: Implications for Product Life-Cycle Management. Religions 10: 589. [CrossRef]

Rocznik Muzułmański 2020. Beger, Rafał, ed. Warszawa: Stowarzyszenie Jedności Muzułmańskiej.

Rozp. MZ. 2020. Rozporządzenie Ministra Zdrowia 13 March 2020, “Dziennik Ustaw" 2020, poz. 433. Available online: https: / / dziennikustaw.gov.pl/D2020000043301.pdf (accessed on 17 March 2021).

Rozp. RM. 2020a. Rozporządzenie Rady Ministrów 31 March 2020, “Dziennik Ustaw” 2020, poz. 566. Available online: https: / / dziennikustaw.gov.pl/D2020000056601.pdf (accessed on 17 March 2021).

Rozp. RM. 2020b. Rozporządzenie Rady Ministrów 19 April 2020, “Dziennik Ustaw" 2020, poz. 697. Available online: https: / / dziennikustaw.gov.pl/D2020000069701.pdf (accessed on 17 March 2021).

Sheikh Saduq. 2020. Al-Chisaal. Warszawa: Stowarzyszenie Jedności Muzułmańskiej.

Simonsen, Lone, Gerardo Chowell, Viggo Andreasen, Robert Gaffey, John Barry, Don Olson, and Cécile Viboud. 2018. A review of the 1918 herald pandemic wave: Importance for contemporary pandemic response strategies. Annals of Epidomology 28: 281-88. [CrossRef] [PubMed]

Stachowska, Ewa. 2020. Religia i religijność w czasie koronawirusa na przykładzie Polski. Perspektywa socjologiczna. Przeglą Religioznawczy 3: 111-26.

Stojkow, Maria. 2018. Polish Ummah? The Actions taken by Muslim Migrants to set up their World in Poland. Central and Eastern European Migration Review 7: 185-96.

Sułkowski, Łukasz. 2020. COVID-19 Pandemic; Recession, Virtual Revolution Leading to De-globalization? Journal of Intercultural Management 12: 1-11. [CrossRef]

Sulkowski, Łukasz, and Grzegorz Ignatowski. 2020. Impact of COVID-19 Pandemic on Organization of Religious Behaviour in Different Christian Denominations in Poland. Religions 11: 254. [CrossRef]

Szajkowski, Bogdan. 1999. An Old Muslim Community of Poland: The Tatars. Regional Issues 4: 27.

Tabaka, Michał. 2020. Przedsiębiorcy Wściekli. Rząd kazAŁ im Zamknąć Zakłady, a do Kościołów Wpuszcza 50 osób. Available online: https:/ / spidersweb.pl/bizblog/przedsiebiorcy-koscioly-wielkanoc/ (accessed on 17 March 2021).

Tamanaha, Brian. 2001. A General Jurisprudence of Law and Society. Oxford: Oxford University Press.

Topidi, Kyriaki. 2019. Religious Freedom, National Identity, and the Polish Catholic Church: Converging Visions of Nation and God. Religions 10: 293. [CrossRef]

Urbanek, Arkadiusz. 2015. Tożsamość cudzoziemców resocjalizowanych w Polsce. Przegląd Więziennictwa Polskiego 88: 85-7.

Wildman, Wesley, and Joseph Bulbulia. 2020. Religion and the COVID-19 pandemic. Religion, Brain E Behavior 10: 115-7.

Włoch, Renata. 2009. Islam in Poland. Between Ethnicity and Universal Umma. International Journal of Sociology 39: 58-67. [CrossRef]

Wright, Robin. 2021. How Iran Became a New Epicentre of the Coronavirus Outbreak. Available online: https://www.newyorker. $\mathrm{com} /$ news/our-columnists/how-iran-became-a-new-epicenter-of-the-coronavirus-outbreak (accessed on 17 March 2021).

Wyrok SN. 2021. Sądu Najwyższego w Warszawie z dnia 17 marca 2021. Sygn. akt II KK 97/21; Sygn. akt II KK 74/21. Available online: http:/ / www.sn.pl/sites/orzecznictwo/orzeczenia3/ii\%20kk\%2097-21.pdf (accessed on 10 May 2021).

Wyrok SR. 2020a. Wyrok Sądu Rejonowego w Leżajsku z dnia 19 października 2020. Sygn. akt II W 353/20. Available online: https:/ / wiadomosci.gazeta.pl/wiadomosci/7,173952,26411814,lezajsk-na-mszy-bylo-zbyt-duzo-osob-sad-uniewinnil-ksiedza.html (accessed on 10 May 2021).

Wyrok SR. 2020b. Wyrok Sądu Rejonowego w Kościanie z dnia 3 czerwca 2020. Sygn. akt II W 71/20. Available online: http: / / www.nomos.org.pl/inne/IIW7120.pdf (accessed on 10 May 2021).

Ząbek, Maciej. 2012. Problemy integracji uchodźców muzułmańskich w Polsce. In Islam w Europie. Bogactwo Różnorodności czy źródło Konfliktów? Edited by Marta Widy-Behiesse. Warszawa: Dialog, pp. 63-71. 